\title{
Özkıyım: Umut Işığını Söndürmek ${ }^{*}$
}

\section{Suicide: Extinguishing the Light at the End of the Tunnel Sunay Firati, Mehmet Aykut Erkii, Seda Kahyaiii}

i Doç. Dr. Çukurova Üniversitesi, Bağımlılık ve Adli Bilimler Enstitüsü, https://orcid.org/0000-0002-9960-0836

iiUzm. Psk. Dan., Çukurova Üniversitesi, Bağımlılık ve Adli Bilimler Enstitüsü, https://orcid.org/0000-0002-4362-2729

iiiHem., Çukurova Üniversitesi, Tıp Fakültesi, Beyin ve Sinir Cerrahisi Yoğun Bakım Ünitesi, https://orcid.org/0000-0002-3793-4734 ÖZ

Amaç: Özkıyım davranışı sadece psikiyatrik değil sosyal, kültürel ve ekonomik sonuçları olan önemli bir halk sağlığı sorunudur. özkıyım davranışının bireylerde sadece bireysel veya toplumsal sorunların sonucu olmayıp temelde biyolojik, psikiyatrik/psikolojik ve toplumsal etmenlerin bir bileşkesi sonucu oluştuğu düşünülmektedir. Bu çalışmada özkıyım girişimi nedeniyle Çukurova Üniversitesi, Tıp Fakültesi, Beyin ve Sinir Cerrahisi Yoğun Bakım Ünitesinde tedavi görmüş olguların geriye dönük değerlendirilmesi amaçlanmıştır.

Gereç ve Yöntem: 2013-2018 yılları arasında, 5 yıl boyunca gelen hastalar arasından, özkıyım girişimi nedeniyle Çukurova Üniversitesi, Tıp Fakültesi, Beyin ve Sinir Cerrahisi Yoğun Bakım Ünitesinde tedavi görmüş toplam 20 olgunun sosyodemografik değişkenleri, psikiyatrik bozukluk varlığı, özkıyım girişimi şekli gibi değişkenler dikkate alınarak, hastane kayıtları, geriye dönük olarak incelenmiştir.

Bulgular: Olguların yaş ortalaması 29,95 $\pm 12,32$ 'dir. Cinsiyetleri değerlendirildiğinde $\% 65$ 'i erkek, \%35'i ise kadındır. Özkıyım girişimi şekilleri incelendiğinde, \%70'i yüksekten atlama, \%30'u ise ateşli silah ile girişimde bulunmuşlardır.

Yapılan analizler sonucunda; olguların medeni durumlarına göre bekarlar \%92,3 oranında yüksekten atlayarak özkıyım girişiminde bulunmuşken, evlilerin oranı $\% 28,6^{\prime}$ dır $(p=0,007)$. Yerleşim bölgesine göre yüksekten atlayarak özkıyım edenlerin oranı \%92,9'dur ( $p=0,003)$. Yüksekten atlayanların \%71,4'ünde bir psikiyatrik bozukluğun varlığı söz konusuyken ateşli silah ile özkıyım girişiminde bulunanların hiçbirinde herhangi bir tanıya rastlanmamıştır. $(p=0,011)$.

Sonuç: Sonuç olarak özkıyım girişimlerinde sosyodemografik özelliklerin ve bunların intihar riski üzerindeki etkilerinin bilinmesi, toplumda özkıyımların önlenmesi ve sağlık çalışanlarına bu konuda önleyici programların oluşturulması bakımından fayda sağlayacağı düşünülmektedir.

Anahtar Kelimeler: Özkıyım girişimi, sosyodemografik özellikler, yüksekten atlama, ateşli silah, yoğun bakım

\section{ABSTRACT}

Objective: Suicidal behavior not only is a psychiatric problem but also has social, cultural and economic impacts to public health. It has been concluded which suicidal behaviors stem from not only individual or social problems but also had been considered as a biological, psychiatric/psychological and social mixture. The aim is to examine the cases which have been treated in Çukurova University, Faculty of Medicine, Neurosurgery Intensive Care Unit retrospectively.

Materials and Methods: Among all the patients which have come between 2013 and 2018, 20 cases which had been treated for suicide attempt in Çukurova University Faculty of Medicine Neurosurgery Intensive Care Unit examined retrospectively by sociodemographic variables, psychiatric disorders and suicide attempt style with hospital records.

Results: According to results the mean age of the cases is $29,95 \pm 12,32$. Gender was separated by $65 \%$ were men, $\% 35$ were women. When suicidal attempts examined it has been found that $70 \%$ of the cases were leap off and $30 \%$ of them have used firearms. According to cases' marital status, $92,3 \%$ of the singles have leapt off while this percentage \%28,6 for married ones $(p=0,007) .92,9 \%$ of the cases were attempted suicide by leap off $(p=0,003)$. While leap off suicides have $71,4 \%$ percentage of a psychiatric history, firearm suicides haven't got any psychiatric history $(p=0,011)$.

Conclusion: To sum up knowledge of risk factors of suicide will be helpful by preventing suicides and to conduct preventive programs.

Key Words: Suicide attempt, sociodemographic features, jumping from height, firearm, intensive care

*Lokman Hekim Dergisi, 2020; 10 (3): 415-424

DOI: $10.31020 /$ mutftd. 703988

e-ISSN: 1309-8004, ISSN 1309-761X

Geliş Tarihi - Received: 15 Mart 2020; Kabul Tarihi - Accepted: 21 Ağustos 2020

iletişim - Correspondence Author: Sunay Fırat <sunayfirat@gmail.com>

Etik Onay: Çukurova Üniversitesi Tıp Fakültesi, Girişimsel Olmayan Klinik Araştırmalar Etik Kurulu (GOKAEK/No: 94-49) 


\section{Giriş}

Özkıyım davranışı, bireylerde sadece bireysel ve/veya toplumsal sorunların sonucu olmayıp temelde biyolojik, psikolojik/psikiyatrik ve toplumsal etmenlerin (ekonomik, sosyal ve kültürel vb.) bir bileşkesi olarak önemli sonuçları olan bir halk sağlığı sorunudur. ${ }^{1}$

Özkıyım davranışına ilişkin sistematik ilk veriler modern sosyolojinin kurucusu olan Emile Durkheim tarafından derlenmiştir. Durkheim'e göre özkıyımlar eylemin niyetine göre değişiklik gösteren bir yapıya sahiptir. Özkıyımları üç tipe ayıran Durkheim, onları "bencil özkıyımlar", "özgeci özkıyımlar" ve "anomik özkıyımlar" olarak adlandırmaktadır. Bu tanımlamaya göre bencil özkıyımlar, bireyin topluma olan bağııı̆ının zayıflaması koşulu ile meydana gelmektedir. Durkehim, özgeci özkıyımları ise bireyin içinde bulunduğu topluma gösterdiği yüksek seviyedeki bağlıı̆̆ın, bireyi toplumun refahı için özkıyım eylemini gerçekleştirmeye yönelttiğini düşünmektedir. Son olarak anomik özkıyımlarda ise toplumun yapısında meydana gelen değişikliklere uyum sağlayamayan bireyin yaşadığı bunalımın rol oynadığı görülmektedir. ${ }^{2}$

Son yıllarda yapılan çalışmalara göre dünyada özkıyım oranlarında önemli bir artış olduğu görülmektedir. Dünya Sağlık Örgütüne göre, her yıl dünyada 1,4 milyon kişi özkıyım sonucu hayatını kaybetmektedir, bu oranın yaklaşık 10-20 kat daha fazlasında ise bireylerin özkıyım girişiminde bulundukları düşünülmektedir. ${ }^{3}$ Son 45 yılda dünyadaki özkıyım oranlarının yaklaşık \%60 artış gösterdiği ve 2020 yılında özkıyım sonucu ölenlerin sayısının ise 1,5 milyona ulaşmasının beklenildiği belirtilmektedir. ${ }^{4}$

Özkıyım, travmanın, kayıpların, sosyal ve kültürel risk faktörlerinin yanında, bireylerin yaş, cinsiyet, eğitim düzeyi, medeni durum, meslek, ekonomik düzey ve yaşadığı yerleşim yeri gibi sosyodemografik özelliklerin de etkilediği, sonuçları çok ciddi olan bir davranış olarak düşünülmektedir. ${ }^{5,6}$ Posner ve arkadaşlarının (2008) yaptıkları ve özkıyım davranışında kadın ve erkek oranlarını karşılaştırdıkları bir çalışmada ise, erkeklerin özkıyım oranı kadınlara kıyasla 3,5 kat daha fazla iken, bir başka çalışmada ise özkıyım girişiminde bulunma oranları kadınlarda erkeklere kıyasla 4 kat daha fazla bulunmuştur. ${ }^{7,8}$

Ülkemizde özkıyım oranlarına bakıldığında; Türkiye İstatistik Kurumu (TÜiK) verilerine göre, ölümle sonuçlanan özkıyım sayısı 2014 yııında 3 bin 169, 2015 yılında \%1,3 artarak 3 bin 211 kişi olduğu belirlenmiştir. Özkıyım eyleminde bulunanların \%72,7'sini erkeklerin, \%27,3'ünü ise kadınların oluşturduğu tespit edilmiştir. ${ }^{6}$

Yine TÜik verilerine göre; 2005-2014 yılları arasında yaş ve cinsiyete göre özkıyım şekilleri değerlendirildiğinde; erkeklerin kadınlara göre daha fazla oranda olduğu, ası, yüksekten atlama ve ateşli silah kullanmanın da en yüksek ilk üç özkıyım şekli olduğu belirtilmektedir. 2014 verileri dikkate alındığında, 2276 erkek bireyin, 789 kadın bireyin özkıyımda bulunduğu tespit edilmiştir. ${ }^{6}$ Tüik verileri özkıyım şekillerine bakıldığında, ilk üç sırada sırasıyla, 1460 birey kendini asarak, 338 birey yüksekten atlayarak ve 795 bireyin ise ateşli silah kullanarak özkıyım girişiminde bulunduğu tespit edilmiştir. ${ }^{6}$ Özkıyım girişiminde bulunan bireylerin bu eylemi tamamlama olasılıkları çok fazla olabileceğinden çoğunun ölümle sonuçlanabileceği düşünülmektedir. Acil servislerde yapılan geriye dönük bir çalışmada, tamamlanmış özkıyımlarda en sık kullanılan yöntemin \%41 ile ası olduğu, bunu \%21 ile yüksekten atlamanın izlediği bildirilmiştir. $^{9}$

Bireyler, tamamlanmamış diğer özkıyım girişim şekillerinden (kimyevi bir madde, kesici bir alet kullanarak vs.) dolayı acil tıp ünitesinden ilgili klinik ve yoğun bakım ünitelerine tedavi amaçlı yönlendirildikleri için hastane içerisinde hastalar dağılmakta dolayısıyla klinik başına düşen sayı da azalabilmektedir. Bu nedenle, yüksekten atlama ve ateşli silah kullanma nedeniyle Acil Tıp polikliniğine getirilen ve özkıyım şekli nedeniyle tedavi edilmesi gerektiği düşünülen bir grup hastanın Beyin ve Sinir Cerrahisi Yoğun Bakım Ünitesine tedavi görmek üzere yatırılmış olma olasılıklarının yüksek olduğu düşünülmektedir. Bu nedenle Beyin ve Sinir 
Cerrahisi Yoğun Bakım ünitesindeki hastaların özkıyım girişimi ve şekli, sosyodemografik değişkenleri, herhangi bir psikiyatrik bozukluğun olup olmadığı gibi değişkenlerin geriye dönük incelenmesi gerektiği düşünülmüştür. Bu çalışmada yüksekten atlama ve ateşli silah kullanılarak özkıyım girişiminde bulunan, hayati tehlike taşıdığı düşünülen kafa travması, omurgadaki ciddi yaralanmaları olan hastaların yatırıldığı kliniklerden olduğu düşünüldüğü için Çukurova Üniversitesi, Tıp Fakültesi, Beyin ve Sinir Cerrahisi Yoğun Bakım Ünitesinde tedavi edilmiş olan olguların geriye dönük olarak sosyodemografik özellikleri, psikiyatrik bozuklukların varlığı, özkıyım şekilleri ve benzer değişkenlerin değerlendirilmesi amaçlanmıştır.

\section{Gereç ve Yöntem}

Çukurova Üniversitesi Tıp Fakültesi, Girişimsel Olmayan Klinik Araştırmalar Etik Kurulu (GOKAEK/No: 94-49) ve gerekli kurum izinleri alındıktan sonra; 2013-2018 yılları arasında özkıyım girişimi nedeniyle Çukurova Üniversitesi Tıp Fakültesi, Beyin ve Sinir Cerrahisi Yoğun Bakım Ünitesine tedavi görmek üzere yatırılmıs olan olguların sosyodemografik değişkenleri, herhangi bir psikiyatrik bozukluğun olup olmadığı, özkıyım girişimi ve özkıyım şekli gibi değişkenler dikkate alınarak son beş yıla ait hastane kayıtları geriye dönük olarak incelenmiş ve toplam 20 olgu tespit edilmiştir.

Özkıyım girişimi nedeniyle Çukurova Üniversitesi Tıp Fakültesi, Acil Tıp polikliniğine getirilen, ilk müdahaleleri ve gerekli rutin tıbbi incelemeleri yapıldıktan sonra adli olgu olarak nitelendirilip Beyin ve Sinir Cerrahisi Yoğun Bakım Ünitesinde gerekli tedavi ve bakımlarının yapılmasına karar verilen hastalar bu üniteye yatırılmaktadır. Adli nitelikli bu hastaların dosyaları, geriye dönük olarak beş yıl incelenmiş ve elde edilen verilerin (Acil Tıp Ünitesinden Beyin ve Sinir Cerrahisi Yoğun Bakım Ünitesine hasta ile birlikte gelen dosyaları ve bilgileri, Yoğun Bakım Ünitesinde yatışları boyunca dosyasına eklenen bilgiler, hastanın yatış sürecinde klinik doktoru tarafından istenen psikiyatri konsültasyonları sonucunda dosyalarına eklenen bilgiler vb.) gerekli analizlerinde SPSS 22,0 istatistik paket programı kullanılmıştır. Sürekli verilerin analizinde; aritmetik ortalama, standart sapma, medyan, minimum ve maksimum gibi tanımlayıcı verilerden yararlanılmıştır. Çalışmanın verilerini oluşturan dosyadaki değişkenler araştırmacılar tarafından hazırlanan veri toplama formu kapsamında incelendiğinde; birtakım kategoriler oluşturulmuştur. Bu kategoriler crosstab yöntemi ile ki-kare analizine tabi tutulmuştur.

\section{Bulgular}

Çalışmamızdaki olguların yaş ortalamalarına bakıldığında toplam yaş ortalaması ve standart sapmasının $29,95 \pm 12,32$ olduğu görülürken kadınlarda bu oran $23,86 \pm 12,54$ iken erkeklerde $33,23 \pm 11,32$ olarak tespit edilmiştir.

Özkıyım girişiminde bulunan ve Beyin ve Sinir Cerrahisi Yoğun Bakım Kliniğine yatırılan hastaların cinsiyetleri değerlendirildiğinde, 13’ünün (\%65) erkek, 7’sinin (\%35) ise kadın olduğu tespit edilmiştir (Şekil 1).

Cinsiyet

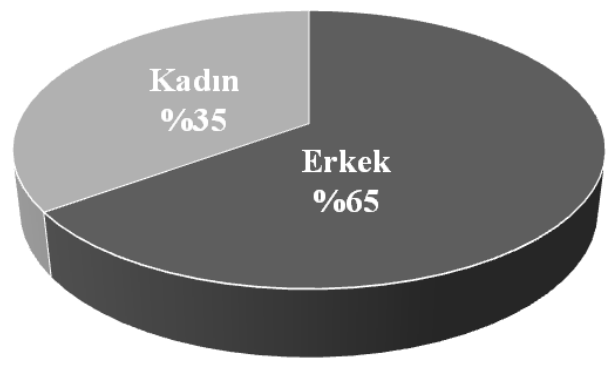

Şekil 1. Beyin ve Sinir Cerrahisi Yoğun Bakım Kliniğine özkıyım girişimi nedeniyle yatıılan hastaların cinsiyetleri 
Eğitim durumları değerlendirildiğinde, 9'u (\%45) lise, 7'si (\%35) ilkokul, 2'si (\%10) üniversite ve 2 (\%10) hastanın ise sadece okuryazar olduğu tespit edilmiştir. Medeni durumlarına bakıldığında 13 (\%65) hastanın evli, 7 (\%35) hastanın ise bekar olduğu belirlenmiştir. Olguların yaşadıkları yer değerlendirildiğinde ise, 14'ünün (\%70) şehirde, 5'inin (\%25) ilçede ve 1'inin (\%5) ise köyde yaşadığı belirlenmiştir (Tablo 1).

Tablo 1. Beyin ve Sinir Cerrahisi Yoğun Bakım Kliniğine özkıyım girişimi nedeniyle yatırılan hastaların sosyodemografik özellikleri

\begin{tabular}{lll}
\hline DEĞişKENLER & & $\mathbf{n}(\%)$ \\
\hline Eğitim durumu & & \\
& Okur-yazar & $2(10)$ \\
& ilkokul & $7(35)$ \\
& Lise & $9(45)$ \\
& Üniversite & $2(10)$ \\
Medeni durum & & \\
& Evli & $13(65)$ \\
Çalışma durumu & Bekâr & $7(35)$ \\
& & \\
& Çalışıyor & $8(40)$ \\
Yerleşim bölgesi & Çalışmıyor & $6(30)$ \\
& Öğrenci & $6(30)$ \\
& ì & $14(70)$ \\
& ilç̧e & $5(25)$ \\
Sosyoekonomik & Köy & $1(5)$ \\
Durumu & & $1(5)$ \\
& Düşük & $16(80)$ \\
& Orta & $3(15)$ \\
\hline
\end{tabular}

Araştırmaya dahil edilen bireylerin 10'nunda (\%50) daha önceden bir psikiyatrik bozukluk tanısının olduğu, bunların 3'ünün (\%15) bipolar bozukluk, 3'ünün (\%15) şizofreni, 2'sinin (\%10) depresyon, 2'sinin ise (\%10) anksiyete bozukluğu tanısının olduğu tespit edilmiştir. Beyin ve Sinir Cerrahisi Yoğun Bakım Kliniğine yatırıldıktan sonra Psikiyatri Anabilim Dalı́na konsülte edilmiş olguların 17'si (\%85) için tedavi önerildiği, daha önce psikiyatrik tanısı olmayan olgulardan, bu konsültasyon sonrasında 6'sına (\%30) anksiyete bozukluğu, 2'sine (\%10) ise depresyon tanısı konulduğu tespit edilmiştir. Olguların alkol, sigara ve madde kullanım durumları incelendiğinde; 9'unun (\%45) sadece sigara kullandığı, 5'inin (\%25) hem sigara hem alkol kullandığı, 6'sının ise (\%30) ise herhangi bir madde kullanmadığı belirlenmiştir. Olguların özkıyım etme şekilleri incelendiğinde, 14'ünün (\%70) yüksekten atlayarak, 6'sının ise (\%30) ateşli silah ile özkıyım girişiminde bulunduğu tespit edilmiştir (Tablo 2).

Tablo 2. Beyin ve Sinir Cerrahisi Yoğun Bakım Kliniğine özkıyım girişimi nedeniyle yatırılan hastaların özkıyım girişimlerine ait bilgiler

\begin{tabular}{lll}
\hline DEĞiŞKENLER & & $\mathbf{n}(\%)$ \\
\hline Özkıyım Şekli & Yüksekten atlama & $14(70)$ \\
& Ateşli silah yaralanması & $6(60)$ \\
Daha Önce Psikiyatrik bir Bozukluğu Olup Olmadığı & & $10(50)$ \\
& Var & $10(50)$ \\
Daha Önce Bir Psikiyatrik Bozukluk Tanının Varlığı & Yok & $10(50)$ \\
& Tanı Konulmamış & $3(15)$ \\
& Bipolar Bozukluk & $3(15)$ \\
& Şizofreni & $2(10)$ \\
Psikiyatrik Konsültasyon Durumu & Depresyon & $2(10)$ \\
& Anksiyete & $18(90)$ \\
Psikiyatrik Konsültasyon Sonrası İlaç Tedavi Önerisi & & $2(10)$ \\
& Konsültasyon yapılmış & $17(85)$ \\
\hline
\end{tabular}




\begin{tabular}{lll}
\hline Yeni Psikiyatrik Tanı Konulma Durumu & Önerilmemiş & $3(15)$ \\
& Tanı konulmamış & $12(60)$ \\
& Depresyon & $2(10)$ \\
Alkol, Sigara ve Madde Kullanımı & Anksiyete Bozukluğu & $6(30)$ \\
& & \\
& Sadece sigara kullanıyor & $9(45)$ \\
& Hem sigara hem alkol kullanıyor & $5(25)$ \\
& Herhangi bir madde kullanmıyor & $6(30)$ \\
\hline
\end{tabular}

Araştırmaya dahil edilen bireylerin, \%5'inin birinci derece, \%5'inin ikinci derece akrabalarında psikiyatrik bir bozukluğun var olduğu, 3 'ünün (\%15) ailesinde psikiyatrik bir bozukluk olduğu; bu aile bireylerinden 2'sinde (\%10) depresyon, 1'inde (\%5) ise anksiyete bozukluğu tanısı olduğu belirlenmiştir (Tablo 3).

Tablo 3. Beyin ve Sinir Cerrahisi Yoğun Bakım Kliniğine özkıyım nedeniyle yatırılan hastaların ailelerindeki ruhsal bozukluk geçmiş̧ine ait bilgiler

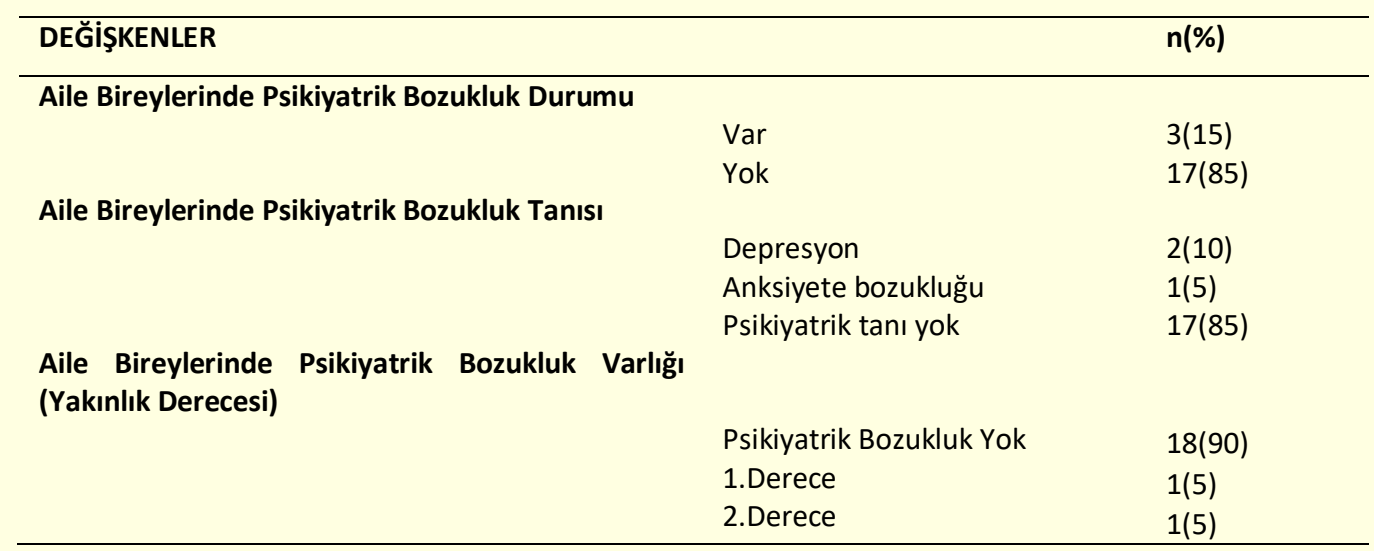

Özkıyım girişiminde bulunan ve Beyin ve Sinir Cerrahisi Yoğun Bakım Kliniğine yatırılan hastaların 4'ünün (\%20) daha önce de özkıyım girişimlerinin olduğu, 16'sının ise (\%80) ilk kez özkıyım girişiminde bulundukları tespit edilmiştir (Tablo 4).

Beyin ve Sinir Cerrahisi Yoğun Bakım Kliniğine özkıyım girişimi nedeniyle yatırılan hastaların medeni durumları ile özkıyım girişiminde bulunma şekilleri, "yüksekten atlayarak" özkıyım girişiminde bulunanlar ile "ateşli silah" ile özkıyım girişiminde bulunanlar arasında istatistiksel olarak anlamlı farklılık tespit edilmiştir $(p<0,05)$. Yüksekten atlayarak özkıyım girişiminde bulunan bireylerin \%92,3'ünün bekar, ateşli silah ile özkıyım girişiminde bulunan olguların \%71,4'ünün ise evli olduğu tespit edilmiştir. Diğer bir deyişle; bekarların \%92,3'ünün "yüksekten atlayarak" özkıyım girişiminde bulundukları, evlilerin \%71,4'ünün ise "ateşli silah" ile özkıyım girişiminde bulundukları belirlenmiştir. Beyin ve Sinir Cerrahisi Yoğun Bakım Kliniğine özkıyım girişimi nedeniyle yatırılan hastaların yaşadıkları yerleşim bölgeleri ile özkıyım girişiminde bulunma şekilleri değerlendirildiğinde; "yüksekten atlayanların" \%92,9'unun şehirde yaşadıkları tespit edilmiştir. ile özkıyım girişimde bulunanların \%87,8'sinin ise kırsal bölgede yaşadıkları tespit edilmiştir. Özellikle "ateşli silah" ile özkıyım girişimde bulunan 3 hastanın kırsal bölgede yaşadıkları ve tedavi sürecinde ölmüş olduğu belirlenmiştir. Buna göre; bireylerin yaşadıkları yerleşim bölgeleri ile özkıyım şekilleri arasındaki farkın anlamlı olduğu tespit edilmiştir $\left(p=0,003 ; X^{2}=11,26\right)$. Beyin ve Sinir Cerrahisi Yoğun Bakım Kliniğine özkıyım girişimi nedeniyle yatırılan hastaların herhangi bir psikiyatrik bozukluğun varlığı ile özkıyım girişiminde bulunma şekilleri değerlendirildiğinde; “yüksekten atlayanların” \%50,0'sinde psikiyatrik bir bozukluk tanısının olduğu, "ateşli silah" ile özkıyım girişimde bulunanların tamamında ise henüz herhangi bir psikiyatrik bozukluk tanısının bulunmadığı tespit edilmiştir $\left(p=0,003 ; X^{2}=8,571\right)$. Beyin ve Sinir Cerrahisi Yoğun Bakım Kliniğine özkıyım girişimi nedeniyle yatırılan hastalar psikiyatrist tarafından 
değerlendirildiğinde; "yüksekten atlayanlar" ve "ateşli silah" ile özkıyım girişiminde bulunan hastaların tamamına psikiyatrik ilaç tedavisi önerildiği tespit edilmiştir (Tablo 5).

Tablo 4. Beyin ve Sinir Cerrahisi Yoğun Bakım Kliniğine özkıyım girişimi nedeniyle yatırılan hastaların daha önceki özkıyım girişimleri, aylara ve yıllara göre sayıları

\begin{tabular}{lll}
\hline DEĞiŞKENLER & n(\%) \\
\hline Daha Önce Özkıyım Girişimi & Var & $4(20)$ \\
Hangi Ayda Özkıyım Girişiminde Bulunulduğu & Yok & $16(80)$ \\
& Ocak & $1(5)$ \\
& Şubat & $2(10)$ \\
& Mart & $1(5)$ \\
& Nisan & $2(10)$ \\
& Mayıs & $2(10)$ \\
& Haziran & $2(10)$ \\
& Temmuz & $3(15)$ \\
& Ağustos & $1(5)$ \\
Hangi Yılda Özkıyım Girişiminde Bulunduğu & Eylül & $4(20)$ \\
& Ekim & $1(5)$ \\
& Kasım & $0(0)$ \\
& Aralık & $1(5)$ \\
& 2013 & $1(5)$ \\
Hangi Mevsimde Özkıyım Girişiminde Bulunduğu & 2018 & $4(20)$ \\
& Kış & $3(15)$ \\
& Ilkbahar & $3(15)$ \\
& Yaz & $8(40)$ \\
& Sonbahar & $1(5)$ \\
& 2015 & $5(25)$ \\
& 2016 & $5(25)$ \\
& 2017 & $4(30)$ \\
& & $4(20)$ \\
\hline
\end{tabular}

Tablo 5. Beyin ve Sinir Cerrahisi Yoğun Bakım Kliniğine özkıyım girişimi nedeniyle yatırılan hastaları medeni durum, yaşadıkları yerleşim yerleri ve psikiatrik bozuklukları ile özkıyım girişiminde bulunma şekillerine ait bilgiler

\begin{tabular}{|c|c|c|c|c|c|}
\hline \multirow[b]{2}{*}{ DEĞişKENLER } & & \multicolumn{2}{|c|}{ INTIHAR ŞEKLI } & \multirow{3}{*}{$\mathrm{X}^{2}$} & \multirow{3}{*}{$\mathbf{p}$} \\
\hline & & \multirow{2}{*}{$\begin{array}{c}\text { Yüksekten Atlama } \\
\mathrm{n}(\%)\end{array}$} & \multirow{2}{*}{$\begin{array}{c}\text { Ateşli Silah } \\
\mathrm{n}(\%)\end{array}$} & & \\
\hline \multirow{2}{*}{\multicolumn{6}{|c|}{ Cinsiyet }} \\
\hline & & & & & \\
\hline & Kadın & $6(85,7)$ & $1(14,3)$ & 1,266 & 0,227 \\
\hline & Erkek & $8(61,5)$ & $5(38,5)$ & & \\
\hline \multicolumn{6}{|l|}{ Medeni Durum } \\
\hline & Bekar & $12(92,3)$ & $1(7,7)$ & 8,802 & 0,007 \\
\hline & Evli & $2(28,6)$ & $5(71,4)$ & & \\
\hline \multicolumn{6}{|l|}{ Yerleşim Yeri } \\
\hline & Şehir & $13(92,9)$ & $1(7,1)$ & 11,26 & 0,003 \\
\hline & Kırsal & $1(20)$ & $5(87,7)$ & & \\
\hline \multicolumn{6}{|c|}{ Psikiyatrik Bozukluk } \\
\hline & Var & $10(100)$ & -- & 8,571 & 0,003 \\
\hline & Yok & $4(40,0)$ & $6(60)$ & & \\
\hline
\end{tabular}

\section{Tartışma}

Özkıyım, birçok şekilde meydana gelebilen, birey ve toplum temelli farklılıklar gösterebilen bir olgu olarak kabul edildiği için genel bir sınıflandırma yapabilmek güçtür. Bunun yanında özkıyım, öngörülebilirlik anlamında olumsuz bir üne sahiptir. Ruh sağlığı alanında geliştirilmiş birçok ölçeğe ve uygulamaya rağmen hangi bireyin ne zaman özkıyım girişiminde bulunabileceği veya nasıl özkıyım girişiminde bulunabileceği tam 
olarak saptanamamaktadır. ${ }^{10,11}$ Ancak önleme çalışmaları bakımından, özkıyım davranışını meydana getiren özellikler ve risk faktörleri ne kadar iyi bilinirse önleyici müdahalelerin o kadar etkili olduğu düşünülmektedir. Özkıyımın biyo-psiko-sosyal bir olgu olduğu düşüncesi ile özkıyıma ilişkin yapılan çalışmaların toplumun tüm katmanlarına yayılması gerekliliği gündeme gelmektedir. Bu bakımından bu çalışma, özkıyım eylemi nedeni ile Çukurova Üniversitesi, Tıp Fakültesi, Balcalı Hastanesine getirilen Beyin ve Sinir Cerrahisi Yoğun Bakım veya Beyin ve Sinir Cerrahisi Servisinde gözlem ve tedavi edilmiş hastaların sosyodemografik özelliklerinin ve söz konusu özkıyım eylemlerini meydana getiren sosyodemografik özelliklerin, herhangi bir psikiyatrik bozukluklarının varlığı, özkıyım şekilleri ve benzer değişkenlerin geriye dönük olarak kayıt tarama esasına dayalı bir şekilde değerlendirilmesi amaçlanmıştır.

Durkheim'den günümüze kadar özkıyımı birçok yönüyle ele alınmıştır. Ancak çoğunlukla özkıyım davranışı yalnızca çevresel değil bireysel etmenlere de dayandığı düşüncesi kabul görmektedir. Yaş, cinsiyet, psikiyatrik bulgular ya da aile içindeki konum gibi çevresel görünmesine rağmen bireyin algısına etki edebilen tüm sosyodemografik özellikler araştırmaların konusu haline gelmiştir. ${ }^{12}$ Çalışmamızın bulgularına göre ise cinsiyet bakımından olguların \%65'i erkek iken \%35'i kadındır. Yalvaç'ın gerçekleştirdiği çalışmaya göre acile başvuran olguların cinsiyet oranlarına bakıldığında kadınların erkeklere göre oranı 1,7 olarak bulunmuştur. ${ }^{13}$ Yine Gür'ün çalışmasında ise özkıyım olguları değerlendirildiğinde tamamlanmış ya da girişim halindeki özkıyım olgularında kadınların çoğunlukta olduğu tespit edilmiştir. ${ }^{14}$ Fakat toplumsal roller bakış açısı ile yaklaşıldığında, ailenin ekonomik anlamda geçim yükünü üstlenen erkeklerin karşılaştıkları stres unsurları bir risk faktörü olarak düşünülebilmektedir. Yapılan bir çalışmaya göre ise bireylerin özkıyım nedenleri arasında ikinci sırada aile geçimsizliği tespit edilmişken üçüncü sırada geçim zorluğu bulunmaktadır. ${ }^{15} \mathrm{Bu}$ açıdan bakıldığında acile başvuran olgularda kadınlarda intihar girişimi oranının yüksek olması beklenmekte ve literatürde bunu desteklemektedir. Ancak ciddi intihar girişimi ile ilgili literatür erkeklerde bu tür intiharların daha yüksek oranda olduğunu belirtmektedir. ${ }^{7,16}$ Bu anlamda çalışmadan elde edilen bulgular literatürle uyumludur.

Çalışmamızın konusu olan olguların yaş ortalamalarına bakıldığında ise toplam yaş ortalaması ve standart sapmasının 29,95 $\pm 12,32$ olduğu görülürken kadınlarda bu oran $23,86 \pm 12,54$ iken erkeklerde $33,23 \pm 11,32$ 'dür. Türkiye' de yapılmış bir başka çalışmaya göre özkıyım eyleminde bulunanların 15-34 yaş grubunda yoğunlaştığı ve kadın olguların erkeklere kıyasla daha erken yaşta özkıyım eyleminde bulundukları saptanmıştır. ${ }^{17}$ Özellikle toplumsal anlamda kadının daha çok stres unsuru ile karşılaşmasının böyle bir eylemin daha erken yaşta ortaya çıkmasına neden olduğu düşünülmektedir. ${ }^{18}$

Çalışmamızın bulgularına göre grubun \%65'ini bekâr bireyler oluşturmaktaydı. Bu açıdan bakıldığında bekarların evlilere kıyasla daha yüksek oranda özkıyım eyleminde bulundukları söylenebilir. Amerika Birleşik Devletleri'nde evli bireylerde özkıyım oranı 11/100.000 iken bu oran hiç evlenmemiş bireylerde yaklaşık iki kat kadardır. ${ }^{17}$ Avrupa'da yapılan bir çalışmaya göre ise özkıyım girişiminde bulunan bireylerin çoğunluğunun bekar, dul ya da yalnız yaşayan bireyler olduğu tespit edilmiştir. ${ }^{19}$ Hastalar yerleşim yerleri bakımından incelendiğinde ise ilde ikamet eden hastaların oranı \%70 bulunmuştur. Gökhan'ın çalışmasına göre ise bu oran \%73,9 il merkezleri, \%26,1 ilçe ve köy olarak bulunmuştur. ${ }^{20}$ Öte yandan bireyler özkıyım eyleminde bulundukları mevsimler bakımından karşılaştıklarında ise olguların mevsimlere dağılımı birbirine yakın (Kış: \%25, ilıbbahar: \%25, Yaz: \%30, Sonbahar: \%20) bulunmuştur. Özkıyımların mevsimsel geçişlerde arttığı fikri Durkheim'in çalışmasına kadar uzansa da yapılan daha güncel çalışmalara göre bu durum her zaman kanıtlanamamaktadır. ${ }^{2,21}$ Durkheim'e göre sosyal aktivitenin yükseldiği ilkbahar ve yaz ayları, sosyal gerilimin artmasına yol açtığı için yılın ikinci yarısında özkıyım olayları artmaktadır. Bu düşünce mevsimsel değişimlerin özellikle de sıcak mevsimlerin sosyal dokuyu değiştirmesi bakımından köy gibi kırsal alanlarda etkili olması beklenmektedir. Ancak yapılan bir çalışmaya göre özellikle özkıyım biçimleri bakımından ortak 
bir desenin var olmadığı saptanmıştır. Şiddetli özkıyım biçimleri olan ateşli silah kullanma, kesme, ezme ve zehirlenme gibi biçimler de dâhil olmak üzere şiddet içermeyen özkıyım biçimlerinde de mevsimsel herhangi bir desen saptanamamıştır. ${ }^{21}$

Çalışmamızın bulgularına göre olguların \%60'ında herhangi bir psikiyatrik tanı bulunmamaktaydı. Bu açıdan bakıldığında, özkıyımın tespit edilmesi ve önlenmesi zor bir olgu olduğu gündeme gelmektedir. Olgular, özkıyım biçimleri bakımından incelendiğinde ise; sosyodemografik değişkenler ile özkıyım biçimleri arasında bazı anlamlı istatistikler saptanmıştır.

Özkıyım biçimleri kültürden kültüre farklı özellikler gösterebilmektedir. Dünya genelinde cinsiyetler arasında farklıık göstermeksizin özellikle $A B D$ hariç, en sık görülen özkıyım biçimi kendini asmadır. ${ }^{22} A B D$ ise ateşli silahlar ile özkıyım girişiminde bulunan olgular bakımından ilk sırayı almaktadır. ${ }^{21}$ Yüksekten atlama yolu ile özkıyım eylemini gerçekleştirme oranlarına bakıldığı zaman ise sıklıkla Singapur ve Hong Kong gibi oldukça kentleşmiş ülkelerin liste başında olduğu görülmektedir. ${ }^{23}$ Çalışmamızın bulgularına göre ise medeni durum değişkeni ile özkıyım biçimleri arasında istatistiksel olarak anlamlı bir ilişki tespit edilmiştir $(p=0,007)$. Buna göre bekârlar \%92,3 oranında yüksekten atlayarak özkıyım eylemini gerçekleştirmişken, bu oran evli bireylerde \%28,6'dır. Singapur'da yapılan bir çalışmaya göre 2000-2004 yılları arasında meydana gelen özkıyım olguları arasından yüksekten atlayarak özkıyım girişiminde bulunan bireylerin çoğunlukla daha genç, bekar ve işsiz olduğu tespit edilmiştir. Bunun yanı sıra yüksekten atlayarak özkıyım eyleminde bulunan bireylerde çoğunlukla bir majör ruhsal bozukluk görüldüğü bu çalışmadan yola çıkıldığında kronik psikiyatrik bozuklukların işlevselliği bozarak bireyin bekâr kalmasına neden olabileceği düşünüldüğünde yüksekten atlama davranışının psikiyatrik bozukluk ve işlevselliğin yitimi ile bağlantılı olarak bekarlarda daha fazla görüldüğü çıkarımı yapılabilmektedir. ${ }^{24}$

Çalışmamızın bulgularına göre yüksekten atlayarak özkıyım eyleminde bulunan olguların çoğunlukla şehir merkezlerinde yaşadığı saptanmıştır $(p=0,003)$. Buradan hareketle özkıyım biçiminin şehirleşme ile ilişkili olduğu çıkarımı yapılabilmektedir. Yüksek binaların olduğu şehirlerde, ateşli silahlar ile özkıyım eylemini gerçekleştirmeye kıyasla daha az şiddetli olan yüksekten atlama ile özkıyım girişiminde bulunma daha sık görülmektedir. ${ }^{21}$ Öte yandan köy gibi kırsal bölgelerde ateşli silah ile özkıyım eylemini gerçekleştirme oranlarına bakıldığında ise şehir ile farklılıklar olduğu görülmektedir. Bu durum kırsal alanlarda silah bulundurmanın avcılık, hayvancılık gibi nedenler ile daha ulaşılıyor olması ile açıklanabilmektedir. Tazmanya adasında yapılan bir çalışmaya göre depresyon gibi kronik ruhsal bozuklukları olan erkeklerin kendini asarak özkıyım girişiminde bulunmak yerine çoğunlukla ateşli silah yoluyla özkıyım eyleminde bulundukları tespit edilmiştir. ${ }^{25}$ Bunun yanı sıra çalışmamızın bulgularına bakıldı̆̆ında istatistiksel olarak anlamlı olmasa dahi erkekler ile kadınlar arasında özkıyım biçimleri arasında yüzdesel bir farklılık gözlenmiştir. Ateşli silahlar ile özkıyım eyleminde bulunan erkeklerin oranı \%83,3 iken kadınlarda bu oran \%16,7'dir. Literatüre göre erkeklerin kadınlara nazaran daha şiddet içeren yöntemlere başvurduğu görülmüştür. ${ }^{26}$ Bunun yanı sıra ateşli silahlara ulaşım ve aile içerisinde silahın kimler tarafından kullanılacağına ilişkin kararların geleneksel bir yön taşıdığı düşünüldüğünde kırsalda yaşayan erkeklerin çoğunluğu oluşturması beklenen bir sonuçtur. Ateşli silahları içeren özkıyım eylemlerinde çoğunlukla daha yaşlı erkeklerin rol oynadığı görülmüştür. ${ }^{27}$ Literatürdeki bu çıkarım bulgularımız ile uyumludur $(40,60 \pm 9,44)$. Ateşli silahlar ile özkıyım girişiminde bulunma oranları bakımından ABD'nin ilk sıralarda olması da yine ABD'nin silah taşıma konusunda diğer ülkelere nazaran daha serbest bir politika izlemesinden kaynaklandığı düşünülmektedir. ${ }^{21}$ Kısacası ateşli silaha ulaşımın daha kolay olması özkıyım eyleminde kullanılma riskini de arttırabilmektedir.

Çalışmamızın bulgularına göre bir psikiyatrik bozukluğun varlığı yüksekten atlayanların \%71,4'ünde görülürken ateşli silah ile özkıyım eyleminde bulunanların hiçbirinde herhangi bir tanı bulunamamıştır $(p=0,011)$. Literatürde psikopatoloji ve özkıyım biçimlerinin ilişkisine yönelik çalışmalara göre en kuvvetli 
ilişki psikotik bozukluklar ve yüksekten atlama arasında bulunmuştur. Çalışmalara göre yüksekten atlayarak gerçekleştirilen özkıyım girişiminden sağ kurtulanlar arasından \%55'inde psikotik bozukluk (şizofreni ve ilişkili bozukluklar) öyküsü mevcutken bu oran ateşli silah kullananlarda \%4 olarak bulunmuştur. ${ }^{28,29}$ Söz konusu yüksek oranların nedeni olarak psikotik bozuklukların gerçeği değerlendirme yetisinde yarattığı bozulmalar ve bilişsel bozukluklar düşünülebilmektedir. Bunun yanı sıra ruhsal bozukluğu olan bireylerin karmaşık planlar yapabilecek durumda olmadıkları, ayrıca ateşli silahlara ulaşma şanslarının da daha düşük olması gerçeği düşünüldüğünde özkıyım eyleminde bulunmak için daha basit bir yol olan yüksekten atlamayı tercih ettikleri sanılmaktadır. ${ }^{30}$ Öte yandan ateşli silah kullanılarak meydana gelen özkıyımların çoğunlukla planlı olmadıkları hatta dürtüsel özkıyım davranışı oldukları düşünülmektedir. ${ }^{31}$ Literatüre göre ise bu yöntemi kullanan bireylerde daha az sıklıkta ruhsal bozukluk görülmektedir. ${ }^{32}$ Bununla birlikte çalışmamızda olduğu gibi ateşli silah kullanarak özkıyım eyleminde bulunan bireylerin çoğunlukla özkıyım girişimi öyküsü bulunmamaktadır. ${ }^{10}$

\section{Sonuç ve Öneriler}

Özkıyım davranışının öncelikli ilk on halk sağlığı problemi olarak tanınması, önleme programlarının araştırmalarını, risk altındaki kişilerin tespiti, tedavisi ve yönetimini, birçok ülkede özkıyım davranışı ile ilgili çalışmaları teşvik etmiştir. ${ }^{33}$

Çalışmanın sınırlılıkları değerlendirildiğinde; çalışma, geriye dönük ve sadece dosya bilgilerindeki verilerden toplanmıştır. Dosyalardaki bilgilerin çoğunluğu hasta ve hasta yakınları tarafından verilmiş olan bilgilerin dosya kayıtlarına geçirilmesi sonucunda elde edilmiş veriler olduğu ve olgu sayısının azlı̆ından dolayı çalışmanın sonuçlarının topluma genelleştirilemeyeceği düşünülmektedir.

Potansiyel olarak sosyal medyanın, mobil teknolojilerin kullanılması özkıyım davranışını etkili bir şekilde önleyebilecek yeni müdahale metodlarından olduğu düşünülmektedir. Özkıyım davranışlarının çoğunlukla önceden kestirilemediği bu nedenle risk faktörlerinin daha iyi belirlenebilmesi için bu tip çalışmaların yaygınlaşmasına gereksinim duyulduğu, bu alanda yapılacak çalışmalarla bu olasılığı azaltmak hedeflenebilmektedir.

Sonuç olarak özkıyım girişiminde bulunmanın risk faktörlerinin bilinmesi, toplumda özkıyımların önlenmesi ve sağlık çalışanlarına bu konuda önleyici programların oluşturulması bakımından fayda sağlayacağı düşünülmektedir.

\section{Bilgi}

Bu çalışma, V. International, IX National Psychiatric Nursing Congress, Novenber 20-23, 2018 (V. Uluslararası IX. Ulusal Psikiyatri Hemşireliği Kongresi, 20-23 Kasım 2018)'de "Sözel Bildiri" olarak sunulmuştur. Yazar çıkar çatışması olmadığını beyan etmektedir.

\section{Etik Onay}

Çukurova Üniversitesi Tıp Fakültesi, Girişimsel Olmayan Klinik Araştırmalar Etik Kurulu (GOKAEK/No: 94-49)

\section{Kaynaklar}

1. O'Connor RC, Nock MK. The psychology of suicidal behaviour. Lancet Psychiatry 2014;1:73-85.

2. World Health Organization (WHO). 2015. Suicide Data. Available at: http://www.who.int/mental_health/prevention/suicide/suicideprevent/en/ (accessed date: 11.07.2019).

3. World Health Organization Programmes: mental health. Suicide prevention (SUPRE) Geneva: (WHO). 2013. Available at: http://www.who.int/mental_health/prevention/suicide/suicideprevent/en/ (accessed date: 11.07.2019).

4. Hawton K, van Heeringen K. Suicide. Lancet 2009;373:1372-1381. 
5. Teti GL, et al. Systematic review of risk factors for suicide and suicide attempt among psychiatric patients in Latin America and Caribbean. Rev Panam Salud Publica 2014;36(2):124-133.

6. Türkiye İstatistik Kurumu (TÜiK).

Available at: http://www.tuik.gov.tr/PreHaberBultenleri.do?id=18626 (accessed date: 11.07.2019).

7. Posner K, et al. Columbia Suicide Severity Rating Scale (C-SSRS). The Research Foundation for Mental Hygiene, Inc, New York, NY. 2008.

8. Welch SS, A Review of the Literatüre on the Epidemiology of Parasuicide in the General Population. Psychiatric Serv 2001;52(3):368-375.

9. Pajonk FG, Gruenberg KAS, Moecke H, Naber D. Suicides and suicide attempts in emergency medicine. Crisis: The Journal of Crisis Intervention and Suicide Prevention 2002;23(2):68-73.

10. Anestis MD. Prior suicide attempts are less common in suicide decedents who died by firearms relative to those who died by other means. J Affect Disord 2016;189:106-109.

11. Durkheim E. [1897]. Suicide: A Study in Sociology. Glencoe, IL: Free Press, 1951.

12. Turecki G, Brent DA. Suicide and suicidal behaviour. The Lancet 2016;387(10024):1227-1239.

13. Yalvaç DH. İntihar Girişiminde Bulunan Bireylerde Psikiyatrik Morbidite, Kişilik Bozukluğu ve Bazı Sosyodemografik ve Klinik Etkenlerle İlişkisi, Uzmanlık Tezi. Malatya: İnönü Üniversitesi Tıp Fakültesi Psikiyatri A.D. 2006.

14. Gür Akgör ST. Acil Servise İntihar Girişimi Nedeni ile Yapılan Başvuruların Demografik ve Klinik Özellikleri. Uzmanlık Tezi, Atatürk Üniversitesi, Tıp Fakültesi, Acil Tıp Anabilim Dalı, Erzurum, 2012.

15. Seydioğlu M. İntihar Girişiminde Bulunan Kişilerin Sosyodemografik Özelliklerinin İncelenmesi, Depresyon ve Sosyal Destek Algısı Açısından Değerlendirilmesi. Yüzüncüyıl Üniversitesi, Sağlık Bilimleri Enstitüsü, Yüksek Lisans Tezi, Van, 2002.

16. Choo CC, Harris KM, Ho RC. (Prediction of lethality in suicide attempts: Gender matters. OMEGA-Journal of Death and Dying 2019;80(1):87-103.

17. Harmancı P. Dünya'daki ve Türkiye'deki İntihar Vakalarının Sosyodemografik Özellikler Açısından İncelenmesi. Hacettepe Üniversitesi Sağlık Bilimleri Fakültesi Dergisi 2015;1(1):1-15.

18. Deniz I ve ark. 1995-2000 Yılları Resmi Kayıtlarından Batman'da Gerçekleşen İntihar ve İntihar Girişimleri Üzerine Bir İnceleme. Sosyal Politika Çalışmaları Dergisi 2001;1(4):1-22.

19. Yüksel N. İntiharın Nörobiyolojisi. Klinik Psikiyatri Dergisi 2001;4:5-15.

20. Gökhan Ş. Özkıyım Nedeni ile Acil Servise Başvuran Olguların Demografik Verilerinin Özkıyım Yöntemlerine Göre Değerlendirilmesi, Uzmanlık Tezi, Dicle Üniversitesi, Tıp Fakültesi, Acil Tıp Anabilim Dalı, Diyarbakır, 2008.

21. Ajdacic-Gross V, et al. Are seasonalities in suicide dependent on suicide methods? A reappraisal. Social Science \& Medicine 2003;57(7):1173-1181.

22. World Health Organization (WHO). 2014. Preventing Suicide: A Global Imperative. Geneva. Available at: https://www.who.int/mental_health/suicide-prevention/world_report_2014/en/ (accessed date: 11.07.2019).

23. Wong PW, et al. Suicides by jumping from a height in Hong Kong: a review of coroner court files. Soc. Psychiatry Psychiatr. Epidemiol 2014;49:211-219.

24. Chia BH, et al. Suicide methods in Singapore (2000-2004): types and associations. Suicide and Life-Threatening Behavior 2011;41(5):574-583.

25. Lester D, Haines J, Williams CL. Firearm suicides among males in Australia: an analysis of Tasmanian coroners' inquest files. Int. J. Men's Health 2012;11:170-176.

26. Chen YY, Park NS, Lu TH. Suicide methods used by women in Korea, Sweden, Taiwan and the United States. Journal of the Formosan Medical Association 2009;108:452-459.

27. Klieve H, Sveticic J, De Leo, D. Who uses firearms as a means of suicide? A population study exploring firearm accessibility and method choice. BMC Med 2009;7:52.

28. De Moore, GM, Robertson AR. Suicide attempts by firearms and by leaping from heights: a comparative study of survivors. Am. J. Psychiatry 1999;156:1425-1431.

29. Kreyenbuhl JA, Kelly DL, Conley RR. Circumstances of suicide among individuals with schizophrenia. Schizophr Res 2002;58;253-261.

30. Huisman A, van Houwelingen CA, Kerkhof AJ. Psychopathology and suicide method in mental health care. Journal of Affective Disorders 2010;121(1-2):94-99.

31. Conner KR, et al. Low-planned suicides in China. Psychol Med 2005;35:1197-1204.

32. Frei $A$, et al. Use of army weapons and private firearms for suicide and homicide in the region of Basel, Switzerland. Crisis 2006;27:140-146.

33. van der Feltz-Cornelis $\mathrm{CM}$, et al. Best practice elements of multilevel suicide prevention strategies: a review of systematic reviews. Crisis 2011;32:319-333. 